cysts and hydrocephalus. An ocular cyst should be ruled out before treatment with albendazole that may exacerbate inflammation. (American Academy of Pediatrics Red Book, $27^{\text {th }}$ ed, Elk Grove Village, IL, AAP, 2006, pp 646-7).

\title{
LYME NEUROBORRELIOSIS AND ALICE IN WONDERLAND SYNDROME
}

Pediatric neurologists at the Floating Hospital, Tufts University, Boston, MA report a 7-year-old boy with Alice in Wonderland syndrome associated with Lyme disease. He initially awakened with a nightmare, scared and screaming, saying that "his mind was running fast" and he heard "baseball fans cheering." He vomited the following day but had no headache. Three nights later he awoke, went down stairs, and was pale and scared. He had repetitive swallowing and lip-smacking and said "my head is running fast." Next evening while reading, the book appeared to be a distance away, and he said the letters were becoming smaller.

During 36 hours of video EEG recording he had 3 events of distorted perception, a feeling of becoming smaller and the book print farther away, none associated with evidence of seizure. A Lyme disease test at the $6^{\text {th }}$ day, performed at the insistence of the mother, was positive. CSF revealed lymphocytes $22 / \mathrm{mm} 3$, protein $23 / \mathrm{mg} / \mathrm{dl}$, and glucose $63 \mathrm{mg} / \mathrm{dl}$. Lyme disease Western blot immunoglobulin $\mathrm{M}$ on $10^{\text {th }}$ day tested positive in serum and CSF. Lyme PCR on CSF was negative and MRI was normal. He was treated with IV ceftriaxone for 21 days, and symptoms resolved after 3 days. He had no rash and no recurrence at 12-month follow-up. No personal or family history of migraine or epilepsy was elicited. Alice in Wonderland syndrome, or metamorphopsia, should be added to the clinical spectrum of Lyme neuroborreliosis, and a high index of suspicion is required in diagnosis. (Binalsheikh IM, Griesemer D, Wang S, Alvarez-Altalef R. Lyme neuroborreliosis presenting as Alice in Wonderland syndrome. Pediatr Neurol March 2012;46;185-186). (Response: Dr Binalsheikh. E-mail: alsheikh55@yahoo.com).

COMMENT. "Curiouser and curiouser!" said Alice, when she grew and expanded like a telescope after eating the cake. Distortions of form, size, movement, color, or sense of time are characteristic of metamorphopsia that may occur as a sensory aura during migraine or frontal lobe epilepsy. A PubMed literature search lists reports of several infectious agents associated with Alice in Wonderland syndrome, including Epstein-Barr virus, varicella, coxsackievirus B1, H1N1 influenza virus, and infectious mononucleosis. Lyme disease in the Tufts' case presents with visual and other illusions without systemic manifestations of neuroborreliosis. Alice in Wonderland syndrome is a benign disorder of childhood caused most frequently by migraine or Epstein-Barr virus infection. (Losada-Del Pozo R et al. Rev Neurol 2011;53(11):641-648).

\section{CEREBRAL MALFORMATIONS}

\section{HEMORRHAGE RISK OF CAVERNOUS MALFORMATION}

Researchers at the Mayo Clinic, Rochester, MN reviewed the records and radiograph data of 292 patients $(47.3 \%$ male) seen between 1989 and 1999 with a 